\title{
Pengaruh Kemanfaatan, Kemudahan Penggunaan dan Promosi terhadap Keputusan Penggunaan $E$-wallet OVO di Depok
}

\author{
Wiwik Widiyanti \\ Universitas Bina Sarana Informatika \\ e-mail: wiwik.www@bsi.ac.id

\begin{tabular}{ccc}
\hline Diterima & Direvisi & Disetujui \\
$23-01-2020$ & $03-02-2020$ & $05-02-2020$
\end{tabular}

\begin{abstract}
Abstrak - Pertumbuhan transaksi online yang semakin meningkat menyebabkan munculnya berbagai macam teknologi baru dibidang keuangan, salah satunya adalah $e$-wallet. Tercatat $38 e$-wallet di Indonesia yang sudah mendapat lisensi dari Bank Indonesia salah satunya adalah OVO. Persaingan antar e-wallet menyebabkan OVO yang juga sebagai e-wallet terpopuler kedua di Indonesia, terus melakukan berbagai inovasi untuk meningkatkan penggunaan OVO. Disamping itu, e-wallet OVO juga terus berupaya untuk mengenalkan masyarakat melalui berbagai promosi. Penelitian ini bertujuan untuk mengetahui seberapa besar pengaruh dari kemanfaatan, kemudahan penggunaan dan promosi baik secara parsial maupun simultan terhadap keputusan penggunaan $e$-wallet OVO oleh masyarakat di Depok. Metode penelitian yang digunakan dalam penelitian ini adalah metode penelitian kuantitatif asosiatif. Responden yang diambil sebesar 100 orang dengan menggunakan metode convenience sampling. Pemrosesan data menggunakan analisis linier berganda dengan bantuan aplikasi IBM SPSS Statistic 21. Penelitian ini menghasilkan kesimpulan bahwa ada pengaruh secara positif dan signifikan baik secara parsial maupun simultan antara variable kemanfaatan, kemudahan penggunaan dan promosi terhadap keputusan penggunaan $e$-wallet $\mathrm{OVO}$.
\end{abstract}

Kata Kunci: Kemanfaatan, kemudahan penggunaan, promosi, keputusan penggunaan, dompet elektronik

\begin{abstract}
Related to online transactions is increasing causing various new technologies in the financial sector, one of which is e-wallet. There are 38 recorded e-wallets in Indonesia that have been licensed by Bank Indonesia, one of which is OVO. Competition between e-wallets causes OVO which is also the second most popular e-wallet in Indonesia, to continue to make various innovations to increase the use of OVO. In addition, OVO e-wallet is also being introduced to introduce the public through various promotions. This study discusses the great benefits, benefits of using and promoting both partial and simultaneous decisions on the use of OVO e-wallet by the people in Depok. The research method used in this research is descriptive quantitative research method. The number of respondents taken was 100 people using convenience sampling method. Data recovery uses multiple linear analysis with the help of SPSS 21 application. This study produces positive and significant conclusions both partially and simultaneously between the benefits, utilization and ease of use and promotion of the use of the OVO e-wallet application..
\end{abstract}

Keywords : expediency, ease of use, promotion, decision on use, e-wallet

\section{PENDAHULUAN}

Dalam era yang serba digital seperti sekarang ini, perkembangan teknologi membawa perubahan pada sistem bertransaksi dari offline ke online. Berikut data transaksi uang digital di Indonesia.

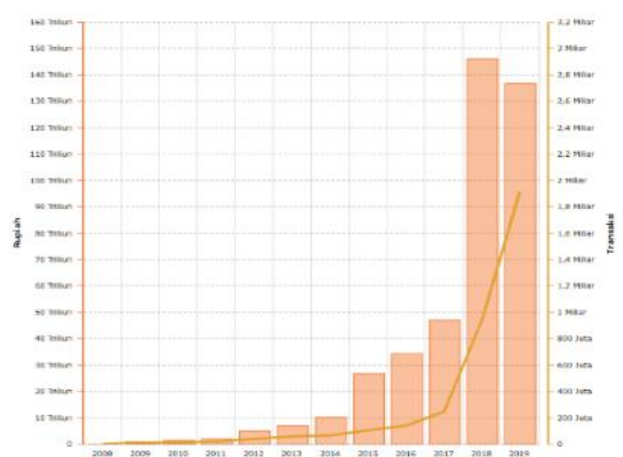

Sumber: Bank Indonesia (2019)

Gambar 1. Volume Transaksi Digital 2008 2019 di Indonesia 
Berdasarkan data terbaru dari Bank Indonesia (BI), nilai transaksi uang digital pada akhir 2018 melonjak 209,8\% menjadi 2,9 miliar transaksi dibandingkan 2017 sebesar 943,3 juta transaksi. Hingga Juli 2019, volume transaksi digital telah mencapai 2,7 miliar transaksi atau mendekati angka pada akhir 2018(Jayani, 2019).

Pembayaran transaksi digital selain menggunakan sistem debit juga menggunakan uang elektronik. Bersumber dari Bank Indonesia, uang digital disebut juga uang elektronik merupakan alat pembayaran yang diterbitkan atas dasar nilai uang yang disetor terlebih dahulu kepada penerbit dimana nilai uang tersebut disimpan secara elektronik dalam suatu media seperti server atau chip yang dikelola oleh penerbit sehingga bukan merupakan simpanan sebagaimana dimaksud dalam undang-undang yang mengatur mengenai perbankan.

Uang elektronik mulai popular di Indonesia pada tahun 2007 dengan produk yang paling awal keluar adalah Flazz dari BCA disusul dengan EMoney dari Bank Mandiri dan Brizzi dari Bank BNI selanjutnya bermunculan elektronik money dari bank-bank lain. Uang elektronik merupakan sebuah inovasi untuk kebutuhan transaksi pembayaran yang bersifat mikro (retail) yaitu pembayaran dalam jumlah sedikit. Bentuk fisik dari uang elektronik adalah berupa kartu atau media lain yang ditanamkan sebuah chip yang didalamnya terdapat nomial uangyang bias digunakan untuk bertransaksi. Penggunaan uang elektronik hanya menempelkan kartu pada sensor alat yang disediakan penerbit pada pedagang (merchant) maka transaksi pembayaran berhasil dilakukan dengan pemotongan saldo yang ada pada kartu. Hal ini mempermudah konsumen karena tidak perlu membawa uang tunai jika ingin melakukan pembayaran, sehingga dapat mengurangi tingkat kriminalitas. Selain itu uang elektronik ini dapat dimiliki oleh nasabah maupun non nasabah dari bank penerbit, kartu juga dapat di isi ulang (top up)(Usman, 2017).

Seiring dengan dikenalnya uang elektronik yang berbasis chip secara luas di tengah-tengah masyarakat, maka banyak perusahaan start up membangun bisnis fintech sehingga tercipta yang disebut e-wallet. E-wallet sebenarnya juga termasuk dalam uang elektronik, perbedaannya pada media penyimpanan uang elektroniknya. Ewallet adalah suatu aplikasi yang terkoneksi dengan internet yang menyimpan nominal uang elektronik. Tidak membutuhkan media kartu, hanya menggunakan smartphone yang pasti dibawa oleh masyarakat saat ini maka $e$-wallet bisa digunakan untuk berbagai macam transaksi.

Berdasarkan data dari Bank Indonesia, sudah ada 38 e-wallet yang mendapat lisensi resmi. Pada tahun 2018, transaksi $e$-wallet mencapai angka USD 1,5 miliar dan diprediksi meningkat menjadi USD 25 miliar pada tahun 2023. Berikut ini adalah hasil riset dari iPrice Group yang bekerjasama dengan perusahaan analisis data terpercaya App Annie mengenai $5 e$-wallet terpopuler di Indonesia pada kuartal 4 tahun 2017 - Kuartal 2 tahun 2019.

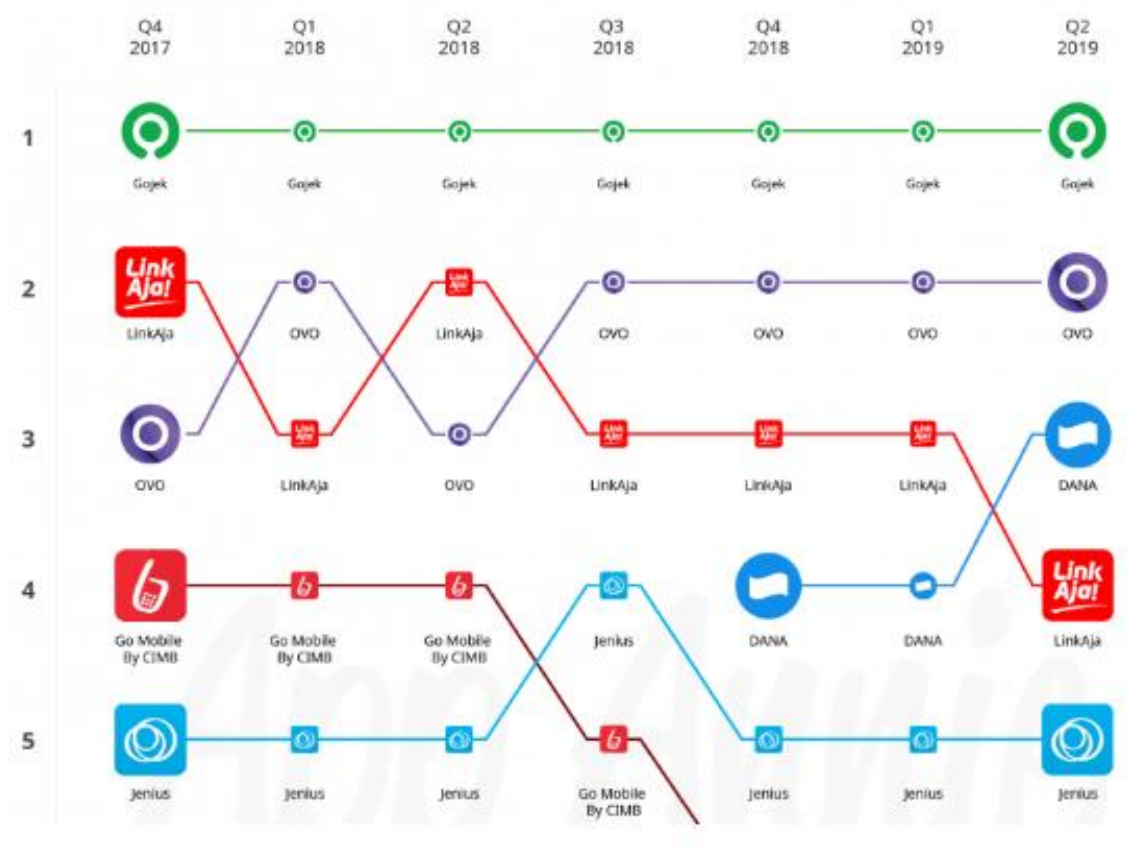

Sumber: (Devita, 2019)

Gambar 2. Aplikasi E-Wallet Paling Popular di Indonesia Tahun 2017 - 2019 
Berdasarkan Aplikasi E-Wallet Paling Popular di Indonesia Tahun 2017 - 2019 ditunjukkan pada kuartal 4 tahun 20173 posisi teratas adalah Gopay disusul dengan Link Aja dan Ovo. Namun pada kuartal 1 tahun 2018 mengalami pergeseran posisi antara OVO dan Link Aja yang berlanjut pada kuartal 2 dan 3 tahun 2018. OVO dan Link Aja terlihat memperebutkan posisi kedua sementara untuk posisi pertama masing stabil dipegang oleh gopay. Urutan posisi mulai stabil pada kuartal ke 4 tahun 2018 sampai dengan kuartal 2 tahun 2019 yaitu dengan gopay pada posisi pertama, OVO pada posisi kedua dan Link Aja pada posisi ketiga.

Aplikasi $e$-wallet OVO telah diunduh oleh lebih dari 10 juta orang, sehingga dapat dikatakan bahwa aplikasi $e$-wallet OVO banyak disukai oleh masyarakat. Oleh karena itu PT Visionet Internasional selaku perusahaan yang mengeluarkan produk e-wallet OVO terus berinovasi untuk meningkatkan pangsa pasar dan jangkauan penggunaan melalui pengembangan merchant sehingga semakin mempermudah masyarakat dalam menggunakan $e$-wallet OVO ini.

Adapun teori kemanfaatan lain menyebutkan bahwa kemanfaatan akan dirasakan jika suatu sistem dapat mempercepat proses, meningkatkan efektifitas dan produktivitas dan bermanfaat bagi individu (Jogiyanto, 2007)

Perkembangan $e$-wallet OVO di tengah masyarakat tidak lepas dari berbagai promosi diantaranya adalah cashback dan diskon serta penggunaan ovo poin yang dapat digunakan untuk bertransaksi kembali sehingga bisa menghemat pengeluaran. Hal ini sejalan dengan adanya teori mengenai promosi penjualan yang merupakan insentif jangka pendek untuk mendorong keinginan dan untuk mencoba atau membeli suatu produk/jasa. Bauran promosi terdiri atas periklanan (advertising), promosi penjualan (sales promotion), hubungan masyarakat (public Relation), dan penjualan langsung (direct marketing) (Kotler \& Amstrong, 2013)

Kemunculan berbagai macam e-wallet
dengan segala macam kelebihan dan
kekurangannya pada akhirnya akan membuat
masyarakat harus selektif membuat keputusan
penggunaan e-wallet yang tepat untuk bertransaksi
dalam kehidupan sehari-hari. Oleh karena itu,
tujuan penelitian ini adalah untuk melihat pengaruh
kemanfaatan, kemudahan penggunaan dan promosi
baik secara parsial maupupn simultan terhadap
keputusan penggunaan $e$-wallet OVO di Depok dan
juga melihat seberapa besar pengaruh
kemanfaatan,kemudahan penggunaan dan promosi

Seperti layaknya teknologi baru pada umumnya, suatu teknologi baru akan dipersepsikan mudah jika sistem tersebut mudah dimengerti, mudah digunakan, mudah dijangkau dan praktis dalam penggunaannya (Venkatesh, etall, 2003).

Adapun kemudahan didefinisikan sebagai sejauh mana seorang percaya bahwa menggunakan suatu teknologi akan bebas dari usaha. Kemudahan penggunaan adalah mudah dipelajari, mudah dipahami, simple dan mudah pengoprasiannya (Jogiyanto, 2007)

Hal lain yang membuat pengguna tertarik untuk menggunakan $e$-wallet OVO adalah manfaat yang didapatnya, diantaranya dapat menghemat waktu pembayaran, membayar dalam nominal yang akurat, dan sangat membantu dalam bertransaksi yang nilainya kecil dengan frekuensi yang tinggi seperti untuk membayar parkir dan lain lain. Manfaat pengguna adalah tingkatan dimana seseorang percaya bahwa penggunaan suatu sistem tertentu akan dapat meningkatkan prestasi kerja orang tersebut (Davis, 1989).

baik terhadap keputusan penggunaan $e$-wallet OVO.

\section{METODOLOGI PENELITIAN}

Metode penelitian yang digunakan dalam penelitian ini menggunakan metode penelitian kuantitatif asosiatif, yang bertujuan untuk mengetahui pengaruh ataupun hubungan antara dua variable atau lebih (Sugiyono, 2015).

Sedangkan proses pengolahan data menggunakan bantuan IBM SPSS Statistic 21. Adapun lokasi penelitian dilakukan di Depok. Populasi dalam penelitian ini adalah masyarakat yang pernah bertransaksi menggunakan $e$-wallet OVO. Sedangkan jumlah sampel sebanyak 100 responden. Pengambilan sampel menggunakan teknik convenience sampling yaitu pengambilan sampel berdasarkan ketersediaan elemen dan kemudahan untuk mendapatkannya jadi siapa saja yang kebetulan ada atau dijumpai menurut keinginan peneliti bisa dijadikan sampel (Silalahi, 2015)

Data diperoleh dengan menyebarkan kuisioner yang menggunakan skala likert sebagai suatu ukuran penilaian responden atas pertanyaan yang diajukan (Sugiyono, 2016).

Variabel dalam penelitian ini ada tiga, yaitu Kemudahan Penggunaan $e$-wallet OVO sebagai X1, Kemanfaatan sebagai X2, Promosi sebagai X3 dan Keputusan Penggunaan $e$-wallet OVO sebagai Y atau variabel terikatnya.

Adapun kerangka pemikiran dari penelitian ini adalah sebagai berikut: 


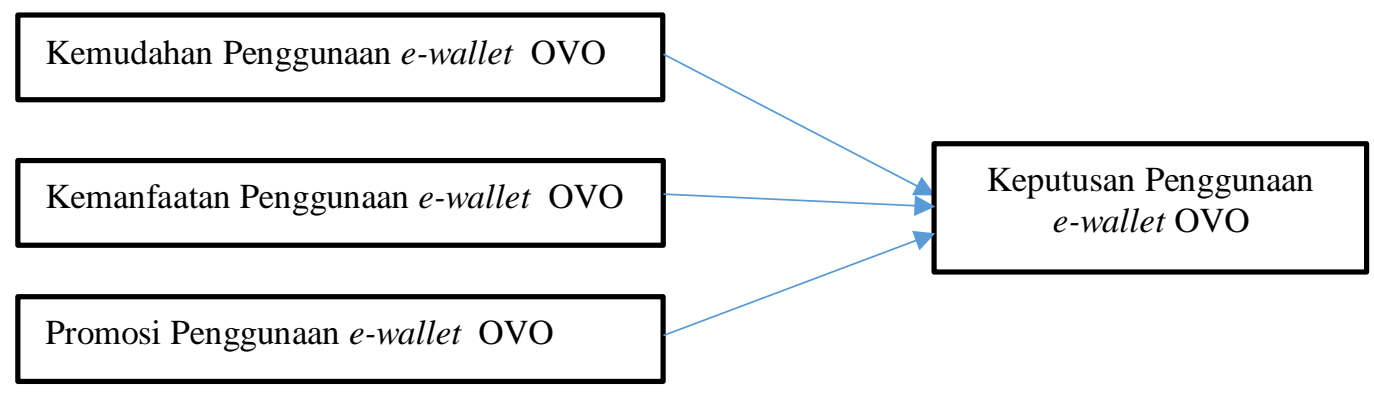

Sumber: Data diolah 2019

Gambar 3. Kerangka Pemikiran Penelitian

Berdasarkan latar belakang dan kajian teori yang telah dijabarkan diatas maka dapat dijelaskan bahwa keputusan penggunaan $e$-wallet OVO akan dipilih seiring dengan kemudahan, kemanfaatan dan promosi yang diperoleh pengguna dalam menggunakan e-wallet OVO ini seperti digambarkan pada gambar 3 .

Teknik analisis yang digunakan adalah analisis regresi berganda, dimana analisis regresi ini bertujuan untuk menjelaskan pola hubungan antar variable. Disebut berganda karena terdapat lebih dari dua variable yang akan dianalisis. Adapun persamaan regresi berganda adalah sebagai berikut:

$\mathrm{Y}=\mathrm{a}+\mathrm{b} 1 \mathrm{X} 1+\mathrm{b} 2 \mathrm{X} 2+\mathrm{b} 3 \mathrm{X} 3+\mathrm{e}$ ................(1)

Dimana:

$\mathrm{Y}=$ Variabel Keputusan Penggunaan $\boldsymbol{e}$-wallet $\mathrm{OVO}$ $\mathrm{a}=$ Konstanta

b1,b2,b3 = koefiesien masing-masing variable

$\mathrm{X} 1=$ Variabel Kemudahan Penggunaan $e$-wallet OVO

$\mathrm{X} 2=$ Variabel Kemanfaatan $e$-wallet $\mathrm{OVO}$

$\mathrm{X} 3=$ Variabel Promosi $e$-wallet $\mathrm{OVO}$

Adapun besarnya pengaruh masingmasing variable di dapat dari hasil koefisien determinasi yang nantinya ada pada output SPSS bagian table model summary.

Penelitian ini menggunakan uji instrument berupa uji validitas dan reliabilitas, uji asumsi klasik berupa uji normalitas, multikolinieritas, heterodeskaditas, dan uji hipotesis menggunakan uji signifikansi parsial dan simultan.

\section{Uji Validitas dan Reliabilitas}

Uji validitas digunakan untuk mengukur valid tidaknya suatu kuisioner. Suatu kuisioner dikatakan valid jika pertanyaan pada kuisioner mampu untuk mengungkapka sesuatu yang akan diukur oleh kuesioner tersebut. Pengukuran validitas dapat dilakukan dengan cara melakukan korelasi antar skor butir pertanyaan dengan tptal skor konstruk atau variable. Pada pengolahan data menggunakan SPSS akan diperoleh $\mathrm{r}$ hitung, sehingga bisa dibandingnkan dengan melihat $\mathrm{r}$ table untuk degree of freedom $(\mathrm{DF})=\mathrm{n}-2$, dalam hal ini $\mathrm{n}$ adalah jumlah sampel. JIka $r$ hitung lebih besar dari $r$ table dan nilai positif maka butir pertanyaan tersebut dinyatakan valid (Sugiyono, 2016).

Uji reliabilitas merupakan alat untuk mengukur sejauh mana pengukuran dari suatu tes tetap konsisten setelah dilakukan berulang-ulang terhadap subjek dan dalam kondisi yang sama. Penelitian dikatakan handal jika memberikan hasil yang konsisten untuk pengukuran yang sama. Tinggi rendahnya reliabilitas ditunjukkan oleh suatu angka yang disebut koefisien reliabilitas yang diperoleh dengan melihat Alpha Cronbach pada hasil pengolahan SPSS. Intrepretasi dari koefisien riliabilitas dapat dilihat pada table 1 berikut ini.

Tabel 1. Cronbach's Alpha

\begin{tabular}{|c|l|}
\hline Nilai Alpha Cronbiach's & \multicolumn{1}{|c|}{ Keterangan } \\
\hline $0,8-1,00$ & Reliabilitas baik \\
$0,6-0,79$ & Reliabilitas diterima \\
$<0,6$ & $\begin{array}{l}\text { Reliabilitas kurang } \\
\text { baik }\end{array}$ \\
\hline
\end{tabular}

Sumber : (Sekaran, 2011)

2. Uji Asumsi klasik

Tujuan pengujian asumsi klasik ini adalah untuk memberikan kepastian bahwa persamaan regresi yang didapatkan memiliki ketepatan dalam estimasi, tidak bias dan konsisten (Priyatno, 2012).

Uji asumsi klasik yang pertama dalam penelitian ini adalah uji normalitas yang bertujuan untuk mengetahui data yang diperoleh tersebut berdistribusi normal atau tidak. Normalitas suatu data penting karena dengan data yang berdistribusi normal maka data tersebut dapat dianggap mewakili suatu populasi(Priyatno, 2012).

Suatu data disebut berdistribusi normal bisa dilihat pada table one sample Kolmogorov-smirnov dengan membaca nilai signifikansi (Asymp Sig 2). Jika nilai signifikansinya kurang dari 0,05 maka data tersebut tidak berdistribusi normal, dan sebaliknya jika nilai signifikansinya lebih dari 0,05 maka data tersebut berdistribusi normal dan untuk memperkuat kesimpulannya maka bisa dilihat pada gambar normal P-P Plot

Uji asumsi klasik berikutnya adalah uji multikolinieritas bertujuan untuk mengujij apakah model regresi ditemukan adanya korelasi (hubungan kuat) antar variable bebas . Model regresi yang baik seharusnya tidak terjadi korelasi diantara variable bebas. Multikolinieritas bisa dilihat pada nilai Tolerance dan VIF nya. Jika 
Tolerance $>0,1$ artinya tidak terjadi multikolinieritas, dan sebaliknya. Bisa juga dilihat dari nilai VIF (Variance Inflation Factor), Jika nilai VIF < 10,0 maka artinya tidak terjadi multikolinieritas.

Uji asumsi klasik yang terakhir dalam penelitian ini adalah uji heterodeskaditas, Tujuan dari uji heterodeskaditas adalah untuk menguji apakah dalam model regresi terjadi kesamaan variance (variasi) dari nnilai residual satu pengamatan ke pengamatan yang lain. Jika nilai variance dari nilai residual antar pengamatan bersifat tetap maka diebut heterodeskaditas. Model regresi yang baik seharusnya yang tidak terjadi gejala heterodeskaditas. Hal ini bisa dilihat pada gambar scatter plot diagram. Jika titik-titik plotnya menyebar dan tidak berpola maka tidak terjadi gejala heterodeskaditas.

3. Uji Hipotesis

Uji hipotesis ini bertujuan untuk menguji hipotesis mana yang ditolak dan hipotesis mana yang diterima. Adapun hipotesis dalam penelitian ini adalah:

H1: Variabel kemudahan, kemanfaatan dan promosi secara simultan berpengaruh positif dan signifikan terhadap keputusan penggunaan $e$-wallet OVO di Depok.

H2: Variabel kemudahan, kemanfaatan dan promosi secara parsial berpengaruh positif dan signifikan terhadap keputusan penggunaan $e$-wallet OVO di Depok.

Pengujian kedua hipotesis diatas berbedabeda. Pada hipotesis pertama adalah menguji secara simultan, dimana untuk melihat diterima atau ditolaknya suatu hipotesis dilihat dari nilai signifikan pada tabel output ANOVA. Jika nilai signifikan < 0,05 maka hipotesis diterima, berlaku untuk sebaliknya.

Pada hipotesis kedua dimana menguji hipotesis secara parsial, dapat dilihat nilai signifikan pada output tabel coefficient. Jika nilai signifikan < 0,05 maka hipotesis diterima, berlaku untuk sebaliknya.

\section{HASIL DAN PEMBAHASAN}

\section{A. Gambaran Karakteristik Responden}

Data yang diperoleh dari penyebaran kuisioner melalui online dengan jumlah responden yang diambil sebanyak 100 orang dengan perbandingan jumlah pria sebesar $48 \%$ dan wanita sebesar $52 \%$ dengan rentang usia sebagai berikut.

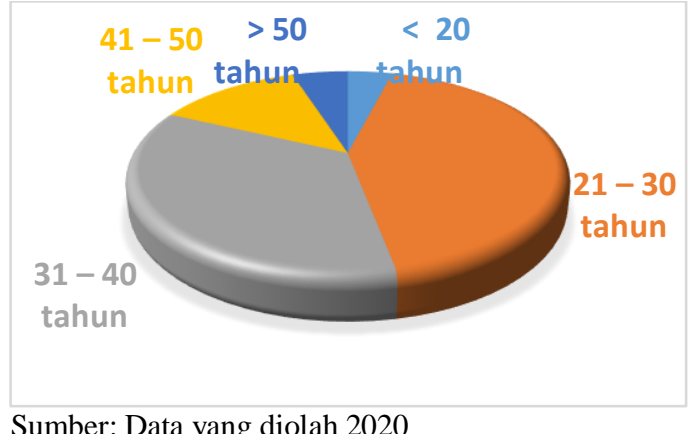

Sumber: Data yang diolah 2020

Gambar 4. Karakteristik Responden Berdasarkan Usia

Berdasarkan usia diperoleh data responden yang terbanyak berusia 21 - 30 tahun sebesar $43 \%$ disusul responden berusia 31 - 40 tahun sebesar $35 \%$, sedangkan di posisi ketiga dan lima adalah responden yang berusia 41 - 50 tahun dan lebih dari 50 tahun sebesar $13 \%$ dan $5 \%$. Posisi terakhir adalah responden dengan usi kurang dari 20 tahun sebesar $4 \%$.

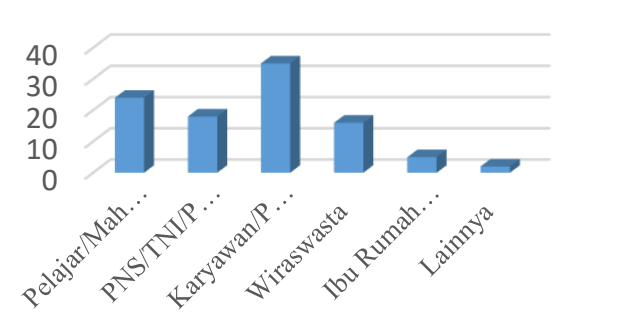

Sumber: Data yang diolah, 2020

Gambar 5. Karakteristik Responden Berdasarkan Pekerjaan

Berdasarkan karakreistik responden berdasarkan pekerjaan diperoleh data jenis pekerjaan responden yang terbanyak adalah karyawan atau pegawai swasta sebesar $35 \%$ dan diikuti dengan pelajar / mahasiswa sebesar $24 \%$.

Tabel 2. Pengeluaran Responden Per Bulan

\begin{tabular}{|c|c|c|c|}
\hline Pengeluaran per Bulan & & Jumlah & Persentase \\
\hline$<$ Rp1.000.000,00 & & 10 & $10 \%$ \\
\hline Rp1.000.000,00 & \multirow[t]{2}{*}{-} & 25 & $25 \%$ \\
\hline Rp3.000.000,00 & & 57 & $57 \%$ \\
\hline Rp3.000.000,00 & \multirow[t]{2}{*}{-} & 7 & $7 \%$ \\
\hline Rp5.000.000,00 & & 1 & $1 \%$ \\
\hline Rp5.000.000,00 & \multirow{2}{*}{-} & & \\
\hline Rp7.000.000,00 & & & \\
\hline$>$ Rp7.000.000,00 & & & \\
\hline Total & & 100 & $100 \%$ \\
\hline
\end{tabular}

Sumber: Data yang diolah, 2020

Berdasarkan pengeluaran per bulan pegeluaran responden per bulan didominasi antara Rp3.000.000,00 sampai dengan Rp5.000.000,00 sebesar 57\% dan Rp1.000.000,00 sampai dengan Rp3.000.000,00 sebesar 25\%. 


\section{B. Hasil Penelitian}

Berikut ini adalah hasil penelitian yang sudah diolah dengan menggunakan SPSS 21.

1.Uji Validitas dan Reliabilitas.

Kuisioner yang berisi butir-butir pertanyaan diuji kelayakannya dengan menggunakan uji validitas dan reliabilitas, yang hasilnya adalah sebagai berikut.

Tabel 3. Hasil Uji Validitas

\begin{tabular}{|c|c|c|c|c|}
\hline Variabel & Butir & $\mathrm{r}$ & $r$ & Keterangan \\
\hline & Pertanyaan & hitung & tabel & \\
\hline Kemudahan & 1 & 0,598 & 0,361 & Valid \\
\hline Penggunaan & 2 & 0,649 & 0,361 & Valid \\
\hline$e$-wallet & 3 & 0,647 & 0,361 & Valid \\
\hline \multirow[t]{5}{*}{ OVO } & 4 & 0,652 & 0,361 & Valid \\
\hline & 5 & 0,401 & 0,361 & Valid \\
\hline & 6 & 0,499 & 0,361 & Valid \\
\hline & 7 & 0,525 & 0,361 & Valid \\
\hline & 8 & 0,466 & 0,361 & Valid \\
\hline \multirow[t]{8}{*}{ Kemanfaatan } & 1 & 0,442 & 0,361 & Valid \\
\hline & 2 & 0,463 & 0,361 & Valid \\
\hline & 3 & 0,457 & 0,361 & Valid \\
\hline & 4 & 0,744 & 0,361 & Valid \\
\hline & 5 & 0,606 & 0,361 & Valid \\
\hline & 6 & 0,546 & 0,361 & Valid \\
\hline & 7 & 0,524 & 0,361 & Valid \\
\hline & 8 & 0,702 & 0,361 & Valid \\
\hline \multirow[t]{8}{*}{ Promosi } & 1 & 0,546 & 0,361 & Valid \\
\hline & 2 & 0,588 & 0,361 & Valid \\
\hline & 3 & 0,398 & 0,361 & Valid \\
\hline & 4 & 0,546 & 0,361 & Valid \\
\hline & 5 & 0,586 & 0,361 & Valid \\
\hline & 6 & 0,588 & 0,361 & Valid \\
\hline & 7 & 0,609 & 0,361 & Valid \\
\hline & 8 & 0,535 & 0,361 & Valid \\
\hline Keputusan & 1 & 0,733 & 0,361 & Valid \\
\hline Penggunaan & 2 & 0,682 & 0,361 & Valid \\
\hline$e$-wallet & 3 & 0,776 & 0,361 & Valid \\
\hline \multirow[t]{7}{*}{ OVO } & 4 & 0,753 & 0,361 & Valid \\
\hline & 5 & 0,748 & 0,361 & Valid \\
\hline & 6 & 0,833 & 0,361 & Valid \\
\hline & 7 & 0,775 & 0,361 & Valid \\
\hline & 8 & 0,515 & 0,361 & Valid \\
\hline & 9 & 0,799 & 0,361 & Valid \\
\hline & 10 & 0,794 & 0,361 & Valid \\
\hline
\end{tabular}

Sumber: Data yang diolah, 2020

Berdasarkan data yang sudah diolah diperoleh hasil uji validitas seperti yang tercantum pada tabel 3 yaitu seluruh butir pertanyaan pada semua variable adalah valid. Hal ini dilihat dari perbandingan antara $r$ hitung dengan $r$ tabel, dimana disebut valid jika $r$ hitung $>r$ table.

Tabel 4. Hasil Uji Reliabilitas

\begin{tabular}{|l|c|c|c|}
\hline \multicolumn{1}{|c|}{ Variabel } & $\begin{array}{c}\text { Cronbach's } \\
\text { Alpha }\end{array}$ & $\begin{array}{c}\text { N of } \\
\text { Items }\end{array}$ & Reliabilitas \\
\hline Kemudahan & 0,862 & 8 & Baik \\
Penggunaan & 0,817 & 8 & Baik \\
Kemanfaatan & 0,852 & 8 & Baik \\
Promosi & 0,938 & 10 & Baik \\
Keputusan & & & \\
$\begin{array}{l}\text { Penggunaan e- } \\
\text { wallet } \text { OVO }\end{array}$ & & & \\
\hline
\end{tabular}

Sumber: Data yang diolah, 2020
Pada hasil uji reliabilitas diperoleh hasil uji reliabilitas untuk semua variable dalam kategori baik. Hal ini bisa dilihat dari besaran Cronbach's alpha masing-masing variable berada di atas 0,8 .

\section{Uji Asumsi Klasik}

Persamaan regresi yang baik adalah yang mempunyai ketepatan estimasi, tidak bias dan konsisten. Oleh karena itu peneliti menguji dalam uji normalitas, uji multikolinieritas dan uji heterodeskaditas berikut ini.

Tabel 5. Hasil Uji Normalitas

One-Sample Kolmogorov-Smirnov Test

\begin{tabular}{|l|l|r|}
\hline \multicolumn{2}{|l|}{} & \multicolumn{1}{c|}{ Total } \\
\hline N & Mean & 100 \\
\hline Normal Parameters ${ }^{\text {a,b }}$ & $\begin{array}{l}\text { Std. } \\
\text { Deviation }\end{array}$ & 11,681 \\
\hline $\begin{array}{l}\text { Most Extreme } \\
\text { Differences }\end{array}$ & Absolute &, 071 \\
\hline & Positive &, 071 \\
\hline & Negative &,- 058 \\
\hline Test Statistic & &, 071 \\
\hline Asymp. Sig. (2-tailed) & &, $201^{\mathrm{c}, \mathrm{d}}$ \\
\hline
\end{tabular}

Sumber: Data yang diolah, 2020

Berdasarkan hasil Uji Normalitas dapat dilihat bahwa data yang diperoleh berdistribusi normal. Hal ini terlihat dari nilai Asymp Sig. (2-tailed) leih dari 0,05. Hal ini diperkuat dengan gambar P-P Plot berikut ini

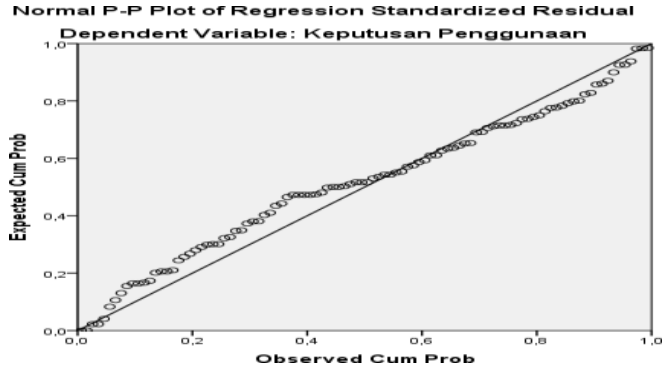

Sumber: Data yang diolah, 2020

Gambar 6. Hasil Uji Normalitas dengan PP Plot

Pada gambar 6 dapat dilihat bahwa titik-titik ploting menyebar di sekitar garis diagonal, hal ini dapat diartikan bahwa data yang diperoleh adalah berdistribusi normal.

Tabel 6. Hasil Uji Multikolinieritas

\begin{tabular}{|l|l|l|}
\hline Variabel Bebas & Tolerance & VIF \\
\hline Kemudahan & 0,638 & 1,605 \\
Penggunaan & 0,485 & 2,110 \\
Kemanfaatan & 0,483 & 2,131 \\
Promosi & & \\
\hline
\end{tabular}

Sumber: Data yang diolah, 2020 
Ada tidaknya gejala multikolinieritas dilihat dari besaran Tolerance dan VIF pada masingmasing variable bebasnya. Pada table 6 , besaran tolerance ketiga variable bebas nya adalah diatas 0,1 sehingga dapat diputuskan bahwa tidak terjadi gejala multikolinieritas, hal ini diperkuat dengan besara VIF yang dibawah 10,0.

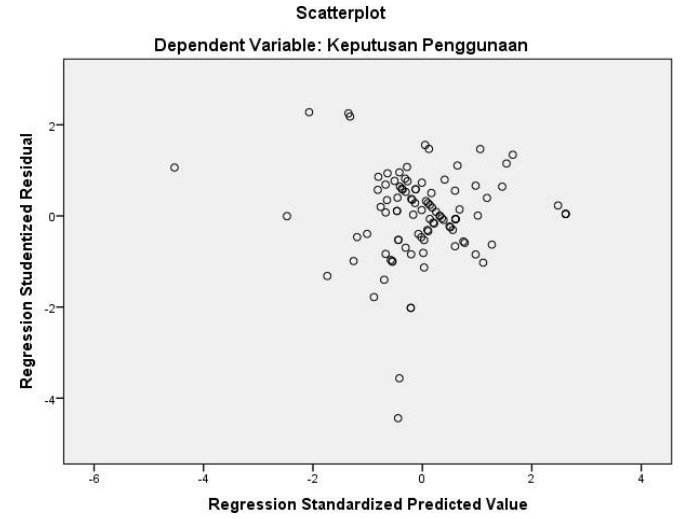

Sumber: Data yang diolah, 2020

Gambar 7. Hasil uji heterodeskaditas

Regresi yang baik adalah regresi yang tidak mempunyai gejala heterodeskaditas. Pada penelitian ini diperoleh hasil bahwa tidak terjadi gejala heterodeskaditas, hal ini terlihat dari gambar 7 dimana pada scatter diagram, titik-titik plot nya menyebar, tidak berkumpul di satu titik dan yang paling penting tidak berpola.

\section{Uji Hipotesis secara Parsial}

Uji hipotesis parsial dilakukan untuk menguji apakah masing-masing variable secara parsial berpengaruh positif dan siginifikan terhadap variable terikat dalam hal ini variable keputusan penggunaan e-wallet OVO. Hasil uji hipotesis secara parsial dapat dilihat pada table 7 berikut ini.

Tabel 7. Hasil Uji Hipotesis Parsial (Uji t)

\begin{tabular}{|c|c|c|}
\hline Model & $\mathrm{T}$ & Sig \\
\hline 1 (Costant) &, 176 &, 861 \\
Kemudahan & 4,154 &, 000 \\
Penggunaan & 3,881 &, 000 \\
Kemanfaatan & 2,719 &, 008 \\
Promosi & & \\
\hline
\end{tabular}

Sumber: Data yang diolah, 2020

Pengambilan keputusan diterima atau tidaknya hipotesis, dapat menggunakan dua acara. Cara yang pertama yaitu dengan melihat nilai Sig pada table. Jika nilai Sig < 0,05 maka hipotesis alternative diterima. Cara kedua yaitu membandingkan nilai $\mathrm{T}$ hitung dengan t table dan diketahui $t$ table sebesar 1,988 .

Pada hipotesis alternative 1 dimana dinyatakan bahwa variable kemudahan penggunaan $e$-wallet OVO berpengaruh positif dan signifikan terhadap keputusan penggunaan $e$-wallet OVO. Hasil uji hipotesis secara parsial pada table 10 terlihat bahwa nilai t hitung sebesar 4,154 dimana nilai tersebut lebih besar dari 1,988 sehingga keputusannya adalah menerima hipotesis alternative ini. Hal ini diperkuat dengan nilai sig pada table diperoleh 0,000 masih kurang dari 0,05.

Diterimanya hasil uji hipotesis alternative 1 secara jelas menjawab tujuan penelitian ini, selain itu juga sejalan dengan penelitian terdahulu yang dilakukan oleh Susilo,dkk (2017) dimana diperoleh hasil bahwa variable kemudahan penggunaan berpengaruh positif dan signifikan terhadap keputusan penggunaan e-toll card Bank Mandiri (Susilo, Ariyanti, \& Sumrahadi, 2017).

Selain itu hasil penelitian ini juga sejalan dengan hasil penelitian yang dilakukan oleh Ardyanto,dkk (2015) dimana juga diperoleh hasil bahwa variable kemudahan berpengaruh secara signifikan dan positif terhadap keputusan pembelian online studi kasus pada www.petersaydenim.com d (Ardyanto, Susilo, \& Riyadi, 2015)

Pada hipotesis alternative 2 dimana dinyatakan bahwa variable kemanfaatan $e$-wallet OVO berpengaruh positif dan signifikan terhadap keputusan penggunaan e-wallet OVO. Hasil uji hipotesis secara parsial pada table 7 terlihat bahwa nilai t hitung sebesar 3,881 dimana nilai tersebut lebih besar dari 1,988 sehingga keputusannya adalah menerima hipotesis alternative ini. Hal ini diperkuat dengan nilai sig pada table diperoleh 0,000 masih kurang dari 0,05 .

Diterimanya hasil uji hipotesis alternative 2 secara jelas menjawab tujuan penelitian ini, selain itu juga sejalan dengan penelitian terdahulu yang dilakukan oleh laksana,dkk (2015) dimana diperoleh hasil bahwa variable kemanfaatan berpengaruh positif dan signifikan terhadap keputusan penggunaan Mobile Banking BRI (Laksana, Astuti, \& Dewantara, 2015).

Senada dengan hasil penelitian diatas, hasil penelitian ini juga sejalan dengan hasil penelitian yang dilakukan oleh Pratiwi (2017) dimana juga diperoleh hasil bahwa variable kemanfaatan berpengaruh secara signifikan dan positif terhadap keputusan keputusan konsumen dalam memilih Grab Car di Surabaya (Pratiwi, 2017).

Pada hipotesis alternative 3 dimana dinyatakan bahwa variable promosi $e$-wallet OVO berpengaruh positif dan signifikan terhadap keputusan penggunaan $e$-wallet OVO. Hasil uji hipotesis secara parsial pada table 7 terlihat bahwa nilai t hitung sebesar 2,719 dimana nilai tersebut lebih besar dari 1,988 sehingga keputusannya adalah menerima hipotesis alternative ini. Hal ini diperkuat dengan nilai sig pada table diperoleh 0,008 masih kurang dari 0,05. 
Diterimanya hasil uji hipotesis alternative3 secara jelas menjawab tujuan penelitian ini, selain itu juga sejalan dengan penelitian terdahulu yang dilakukan oleh heryanto (2015) dimana diperoleh hasil bahwa variable promosi berpengaruh positif dan signifikan terhadap keputusan pembelian mesin crusher penghancur plastik.

Disamping itu hasil penelitian ini juga sejalan dengan hasil penelitian yang dilakukan oleh Nurhayati (2017) dimana juga diperoleh hasil bahwa variable promosi berpengaruh secara signifikan dan positif terhadap keputusan keputusan pembelian handphone merek Samsung di Yogyakarta (Nurhayata, 2017).

\section{Uji Hipotesis secara Simultan}

Uji hipotesis simultan dilakukan untuk menguji apakah variable independen secara simultan (bersamaan) berpengaruh positif dan siginifikan terhadap variable terikat dalam hal ini variable keputusan penggunaan $e$-wallet OVO. Hasil uji hipotesis secara simultan dapat dilihat pada table 8 berikut ini.

Tabel 8. Uji Hipotesis Secara Simultan

\begin{tabular}{|l|r|r|r|c|c|}
\hline \multicolumn{1}{|c|}{ Model } & \multicolumn{1}{|c|}{ Sum of } & Df & Mean & F & Sig \\
\hline & Square & & Square & & \\
\hline Regression & 1723,638 & 3 & 617,209 & 54,191 &, $000^{\circ}$ \\
Residual & 977,692 & 96 & 11,215 & & \\
Total & 2701,330 & 99 & & & \\
\hline
\end{tabular}

Sumber: Data yang diolah , 2019

Pada uji hipotesis secara simultan diperoleh nilai $\mathrm{F}$ sebesar 54,191 hal ini bias diartikan bahwa hipotesis alternative yang menyatakan bahwa variabel kemudahan penggunaan $e$-wallet OVO, kemanfaatan dan promosi secara parsial berpengaruh positif dan signifikan terhadap keputusan penggunaan $e$-wallet OVO di Depok, diterima. Hal ini disebabkan nilai $\mathrm{F}$ hitungn $>\mathrm{F}$ table dimana $\mathrm{F}$ table sebesar 2,70 dan didukung dengan nilai signifikansi sebesar 0,000 dimana syarat diterimanya hipotesis alternative adalah nilai signifikansi yang kurang dari 0,05.

Hasil uji hipotesis secara simultan ini sekaligus menjawab tujuan penelitin yang telah dipaparkan diatas dimana terdapat pengaruh signifikan dan positif antara kemanfaatan, kemudahan penggunaan dan promosi secara simultan terhadap keputusuan penggunaan $e$-wallet OVO.

\section{Analisis Regresi Berganda}

Regresi berganda bertujuan untuk melihat pola hubungan antara variable independen dalam penelitian ini adalah variable kemanfaatan, kemudahan penggunaan $e$-wallet $\mathrm{OVO}$ dan promosi terhadap keputusan penggunaan $e$-wallet OVO.

Tabel 9. Hasil Analisis Regresi Linier Berganda

\begin{tabular}{|c|c|c|c|}
\hline & \multicolumn{3}{|c|}{ Coefficients $^{\mathrm{a}}$} \\
\hline & \multicolumn{2}{|c|}{$\begin{array}{c}\text { Unstandardizes } \\
\text { Coefficient }\end{array}$} & $\begin{array}{l}\text { Standardized } \\
\text { Coefficient }\end{array}$ \\
\hline Model & $\mathrm{B}$ & Std.Error & Beta \\
\hline 1. (Constat) &, 552 & 13,146 & \\
\hline Kemudahan & ,493 & ,126 & ,347 \\
\hline Penggunaan & ,468 & ,126 &, 352 \\
\hline $\begin{array}{l}\text { Kemanfaatan } \\
\text { Promosi }\end{array}$ &, 286 &, 118 & ,237 \\
\hline
\end{tabular}

Berdasarkan Hasil Analisis Regresi Linier Berganda diperoleh persamaan regresi:

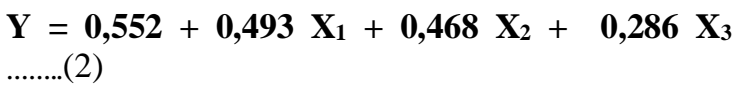
........(2)

Hal ini dapat diinterpretasikan bahwa keputusan penggunaan e-wallet OVO tanpa ada variable bebas adalah sebesar 0,552 unit. Sedangkan jika kenaikan 1 unit variable kemudahan penggunaan e-wallet OVO (X1) sementara variable lain tidak mengalami kenaikan maka keputusan penggunaan $e$-wallet OVO akan mengalami kenaikan sebesar 0,493 unit. Sementara itu jika kenaikan 1 unit variable kemanfaatan (X2) dan variable lain tidak mengalami kenaikan maka keputusan penggunaan e-wallet OVO akan mengalami kenaikan sebesar 0,468 unit. Adapun kenaikan 1 unit variable promosi (X3) sementara variable lain tidak mengalami kenaikan maka keputusan penggunaan e-wallet OVO akan mengalami kenaikan sebesar 0,286 unit.

6. Koefisien Determinasi $\left(\mathrm{r}^{2}\right)$

Pada analisis koefisien determinasi dimaksudkan untuk melihat seberapa besar pengaruh variable kemudahan penggunaan, kemanfaatan dan promosi terhadap keputisan penggunaan $e$-wallet OVO yang dapat dilihat pada table 10. 
Tabel 10. Hasil Koefisien Determinasi $\left(\mathrm{R}^{2}\right)$ Model Summary ${ }^{\mathrm{b}}$

\begin{tabular}{|l|c|c|c|c|}
\hline Model & $\mathrm{R}$ & $\mathrm{R}$ Square & $\begin{array}{c}\text { Adjusted R } \\
\text { Square }\end{array}$ & $\begin{array}{c}\text { Std. Error of } \\
\text { the Estimate }\end{array}$ \\
\hline 1. &, $795^{\mathrm{a}}$ &, 632 & & 3,347 \\
& & &, 347 & \\
& & &, 352 & \\
& & &, 237 & \\
\hline
\end{tabular}

a. Predictors: (Constant), Promosi, Kemudahan, Kemanfaatan

b. Dependent Variable: Keputusan Penggunaan Sumber : Data diolah, 2020

Berdasarkan data Hasil Koefisien Determinasi $\left(\mathrm{R}^{2}\right) \quad$ Model Summary ${ }^{\mathrm{b}}$ diperoleh koefisien determinasi sebesar 0,632 yang dapat di intrepretasikan sebagi nilai pengaruh ketiga variable independen (kemanfaatan, kemudahan penggunaan dan promosi) terhadap keputsan penggunaan $e$-wallet OVO sebesar 0,632 atau $63,2 \%$, selebihnya dipengaruhi oleh faktor lain diluar penelitian.

\section{KESIMPULAN}

Berdasarkan hasil penelitian yang telah dipaparkan diatas, maka penelitian ini telah berhasil menjawab tujuan penelitian dimana baik secara simultan maupun parsial terdapat pengaruh siginifikan dan positif antara kemanfaatan, kemudahan penggunaan dan promosi terhadap keputusan penggunaan $e$-wallet OVO di Depok.

Penelitian ini juga menghasilkan beberapa temuan penelitian mengenai pentingnya variabel kemanfaatan, kemudahan penggunaan dan promosi terhadap keputusan penggunaan e-wallet OVO yang dihasilkan dari jawaban kuisioner penelitian.

Pada variable kemudahan penggunaan, ditunjukkan dengan responden yang merasa bahwa cara penggunaan e-wallet OVO sangat mudah dipahami dan juga praktis. Tidak hanya itu, responden merasa terbantu dengan adanya e-wallet OVO bias menjadi alternative pengganti uang tunai sehingga tidak perlu lagi membawa uang tunai jika bepergian, cukup dengan scan aplikasi ovo maka transaksi sudah bias berjalan. Jaringan e-wallet OVO juga sangat luas, baik dalam sektor $e$ commerce, toko offline, toko kuliner maupun transportasi. Hal tersebut merupakan salah satu alasan responden dalam mengambil keputusan penggunaan e-wallet OVO.

Pada variable kemanfaatan, ditunjukkan dengan responden yang merasakan kecepatan transaksi saat menggunakan e-wallet OVO dan juga ketelitian dalam pembayaran sampai dengan nominal terkecil sehingga tidak diperlukan lagi pengembalian uang. Hal yang menarik dari $e$-wallet OVO yang lain adalah dapat digunakan untuk membayar listrik, membeli pulsa dan lain-lain. Hal tersebut merupakan salah satu alasan responden dalam mengambil keputusan penggunaan e-wallet OVO

Pada variable promosi, responden sangat senang dengan banyaknya promosi cashback maupun diskon saat bertransaksi menggunakan ewallet OVO, sehingga akan terus menggunakan $e$ wallet OVO pada setiap transaksinya.

Walaupun e-wallet OVO mempunyai banyak kelebihan, ternyata $e$-wallet OVO mempunyai beberapa kekurangan, diantaranya para pengguna harus selalu mempunyai paket data ketika sedang bertransaksi karena aplikasi $e$-wallet OVO terkoneksi dengan internet, dan juga keluhan lain dari pengguna adalah seringnya aplikasi $e$-wallet OVO melakukan update. Hal lain yang tidak membuat nyaman pengguna adalah ketika top up melalui bank tertentu dikenakan biaya admin. Tentunya hal ini bias menjadikan pertimbangan penyedia aplikasi $e$-wallet OVO untuk terus berinovasi dan meningkatkan pelayanannya.

\section{REFERENSI}

Ardyanto, D., Susilo, H., \& Riyadi. (2015). Pengaruh Kemudahan dan Kepercayaan Menggunakan E-Cmmerce terhadap Keputusan Pembelian Oonline ( Survei Pada Konsumen www.petersaysdenim.com ). Jurnal Administrasi Bisnis, 22(1), 1-8.

Davis, F. D. (1989). Perceived Usefulness, Perceived Ease of Use, and User Acceptance of Information Technology. MIS Quarterly, 13, n, 319-340. Retrieved from www.jstor.org/stable/249008

Devita, V. D. (2019). Siapa Aplikasi E-wallet dengan Pengguna Terbanyak di Indonesia? Retrieved January 23, 2020, from https://iprice.co.id/trend/insights/e-walletterbaik-di-indonesia/

Heryanto, I. (2015). Analisis pengaruh produk, harga, distribusi, dan promosi terhadap keputusan pembelian serta implikasinya pada kepuasan pelanggan. Jurnal Ekonomi, Bisnis \& Entrepreneurship, 9(2), 80-101.

Jayani, D. H. (2019). Transaksi Uang Elektronik Melonjak 209,8\% pada 2018. Retrieved from https://databoks.katadata.co.id/datapublish/20 19/09/23/transaksi-uang-elektronik-melonjak2098-pada-2018

Jogiyanto, H. M. (2007). Sistem Informasi Keperilakuan (Revisi). Yyogyakarta: Andi.

Kotler, P., \& Amstrong, G. (2013). Prinsip-Prinsip Pemasaran Edisi Ketujuh (7th ed.). Jakarta: Erlangga.

Laksana, G. B., Astuti, E. S., \& Dewantara, R. Y. (2015). Pengaruh Persepsi Kemanfaatan, Persepsi Kemudahan Penggunaan, Persepsi Resiko dan Persepsi Kesesuaian terhadap Minat Menggunakan Mobile Banking (Studi 
Pada Nasabah Bank Rakyat Indonesia ( BRI ) Kantor Cabang Rembang, Jawa Tengah ). Jurnal Administrasi Bisnis, 26(2), 1-8.

Nurhayata, S. (2017). Pengaruh Citra Merek, Harga dan Promosi terhadap Keputusan Pembelian Handphone Samsung di Yogyakarta. Jurnal Bisnis, Manajemen, Dan Akuntansi, IV(2), 60-69.

Pratiwi, A. (2017). Analisis Faktor yang Mpengaruhi Keputusan Konsumen dalam Memilih Grab Car di Surabaya. Sekolah Tinggi Ilmu Ekonomi Indonesia.

Priyatno, D. (2012). Belajar Cepat Olah Data Statistik dengan SPSS. Yogyakarta: Andi.

Sekaran, U. (2011). Research Methods For Business (Metode Penelitian Untuk. Bisnis). Jakarta: Salemba Empat.

Silalahi, U. (2015). Metode Penelitian Sosial Kuantitatif. Bandung. Bandung: Refika Aditama.
Sugiyono. (2015). Metode Penelitian Kuantitatif, kualitatif dan $R \& D$. Bandung: Alfabetha.

Sugiyono. (2016). Metode Penelitian Kuantitatif dan $R \& D$. Bandung: Alfabeta.

Susilo, W. T., Ariyanti, M., \& Sumrahadi. (2017). Pengaruh Daya Tarik Promosi, Persepsi Kemudahan, Persepsi Kemanfaatan dan Harga terhadap Minat Beli E-TOLL CARD BANK MANDIRI. E-Proceeding of Management Telkom Univerysty, 4(1), 25-31.

Usman, R. (2017). Karakteristik uang elektronik dalam sistem pembayaran. Yuridika, 32(1), 134-166.

Venkatesh, V., Morris, M. G., Davis, G. B., \& Davis, F. D. (2003). U SER A CCEPTANCE OF I NFORMATION T ECHNOLOGY : T OWARD A U NIFIED V IEW 1. MIS Quarterly, 27(3), 425-478. 